\title{
Trabanttal a Föld körül
}

\section{Orosz-magyar küldetés az ửridőjárás vizsgálatában}

A z embert - amióta öntudatra ébredt - foglalkoztatja az őt körülvevő világ. Ez természetes, hiszen mindaz, ami körülveszi, egyszerre jelenti számára a létét fenyegető veszélyforrást és az életben maradáshoz szükséges feltételeket.

Az ember kapcsolatát a környező világgal, és a Világegyetemmel összefüggő megfigyeléseit már a történelem előtti időkből is őrzik azok a monolitikus kultúrához tartozó lenyűgöző építmények, amelyeket Nagy-Britanniától Máltáig szerte a világon megcsodálhatunk. Láthatjuk, hogy az ember nemcsak megfigyelte az őt körülvevő világot, de annak ciklikusságát, törvényszerűségeit is igyekezett leírni, mivel jól érzékelhetően ez befolyásolta környezetének állapotát és a saját mindennapi életét is. Elég, ha a Hold és a Föld mozgásának hatásaként fellépő árapály jelenségre gondolunk, és máris megértjük, milyen nagy jelentőségü volt az emberiség korai „űrkutatási tevékenysége” ahhoz, hogy felismerje, mi és hogyan hat rá a környezetében.

Az ókor és a középkor (Kr. u. 180-tól Kopernikuszig) még jórészt a ptolemaioszi, geocentrikus világképet vallotta magáénak, amelyben minden a legtökéletesebb, azaz gömb alakban rendeződött el, e tökéletesen megszerkesztett világnak a középpontjában pedig a Föld állt, körülvéve gömbhéjakkal, amelyeket szféráknak neveztek el. Minden égitest, beleértve a Napot is, ezekben a szférákban keringett a Föld körül. A csillagokon túl pedig, a mennyben énekeltek az angyalok, ezt nevezték a szférák zenéjének.

Mára világunkról jóval többet tudunk, és bár a Világegyetemről alkotott képünk egyfelől kevésbé költői, másfelől, ahogy nő az ismeretanyagunk, úgy tárul elénk egyre varázslatosabban kialakulásának, szerkezetének és működésének csodája.
Ma már tudjuk, hogy a folyamatosan táguló Világegyetemen belül szűkebb hazánk, a Naprendszer heliocentrikus, azaz minden planéta, köztük Földünk is a Nap körül kering. Mind a Naprendszer, mind Földünk körül megtalálhatók a réteges szerkezetek, azaz a szférák mégis léteznek, ha másképpen is, mint őseink hitték. A Voyager ürszondák, amelyek több mint négy évtizede úton vannak, már elérték Naprendszerünk peremét (sőt, a Voyager-1 már 2012-ben elhagyta az összetett, külső lökéshullámzónát is, és kiért a csillagközi térbe) és méréseikből jól láthatóan kirajzolódik előttünk az úgynevezett helioszféra - amit a Voyager-2 épp 2018-ban hagyott el -, a Naprendszert övező bonyolult mágneses erővonalkép és részecskesugárzási övek együttese.

A Földet pedig szintén réteges szerkezetben övezik szférák. A Földet körülvevő, 12-15km magasságig érő legalsó réteg, a troposzféra magában foglalja a légkör 99\%-át. A földi időjárás jelenségeinek túlnyomó része itt zajlik. Fölötte további szférák, rétegek vannak (sztratoszféra, mezoszféra), ahol a földi élet számára döntő fontosságú fizikai folyamatok zajlanak, elég, ha a magaslégköri ózonréteg szerepére gondolunk a napfény ultraibolya sugárzásának megszűrésében.

80-90 km felett kezdődik az ionoszféra, ami 1000 km felett már a magnetoszférában folytatódik, amely réteg a Föld Nap felőli oldalán 10, a földárnyékban akár 1000 földsugár távolságig nyúlik ki (1. ábra). E két réteg már a meteorológiai folyamatok számára ritka, ionizált részecskék semleges elegyeként (plazmaként) nem játszik közvetlen szerepet a földi időjárásban. Azonban az űrkutatásból ma már tudjuk, hogy szerepe legalább annyira fontos, szó szerint életbevágó, mivel ebben a tartományban már a földi mágneses tér és a kozmikus hatások kölcsönhatása dominál: ezt nevezzük űridőjárásnak. Az űridőjárás nem korláto-
ÖSSZEFOGLALÁS: Napjaink egyik legfontosabb ürkutatási területe az úridőjárás vizsgálata. A Földet folyamatosan kozmikus hatások érik, az emberi civilizáció pedig ma már nem tud müködni a világürt is használó szolgáltatások nélkül. Az úridőjárási vizsgálatok egyik legfontosabb része a Föld körüli plazmaszféra elektromágneses folyamatainak vizsgálata és értelmezése. Ebben a munkában kiemelt szerepet kapnak magyar fejlesztések és mérések, számos nemzetközi program lényeges részét alkotva. E programok között is kiemelkedő a közös orosz-magyar Trabant ürkísérlet, amely várhatóan 2022-ben startolva, minden eddiginél pontosabb és részletesebb üridőjárási hullámméréseket hajt majd végre. A mikromühold legnagyobb részének megépítése magyar üripari és ürkutatási szereplők feladata lesz.

KULCSSZAVAK: üridőjárás, ionoszféraszféra, elektromágneses hullámterjedés, mühold
ABSTRACT: Today, a very important topic of the space research investigations is the space weather. The Earth is continuously exposed to cosmic influences, furthermore, the human civilization is unable to operate without the global services using the space. An essential part of the space weather investigation is the monitoring and analysis of the electromagnetic phenomena in the plasmasphere surrounding the Earth. Hungarian measurements and developments play emphasized role in numerous international scientific programs and Hungarian devices are integrated parts of these experiments. A significant program of the Russian-Hungarian space cooperation is the Trabant space mission. After the expected launch in 2022, this microsatellite will realize wave-measurements with extra high accuracy and resolution in the ionosphere. The construction of the largest part of the satellite is the task of Hungarian space scientists and space engineers.

KEY WORDS: space weather, ionosphere, electromagnetic wave propagation, satellite

Ph.D., tudományos főmunkatárs, ELTE Geofizikai és Űrtudományi Tanszék, Ürkutató Csoport, ORCID: 0000-0003-4897-9900

** Ph.D., tudományos főmunkatárs, MTA-ELTE Geológiai, Geofizikai és Ürtudományi Kutatócsoport, ELTE Geofizikai és Ürtudományi Tanszék, Ürkutató Csoport

*** Az MTA doktora, egyetemi tanár, ELTE Geofizikai és Ürtudományi Tanszék, Ürkutató Csoport, MTA CSFK

**** Az MTA doktora, egyetemi magántanár, ELTE Geofizikai és Ürtudományi Tanszék, Ürkutató Csoport 


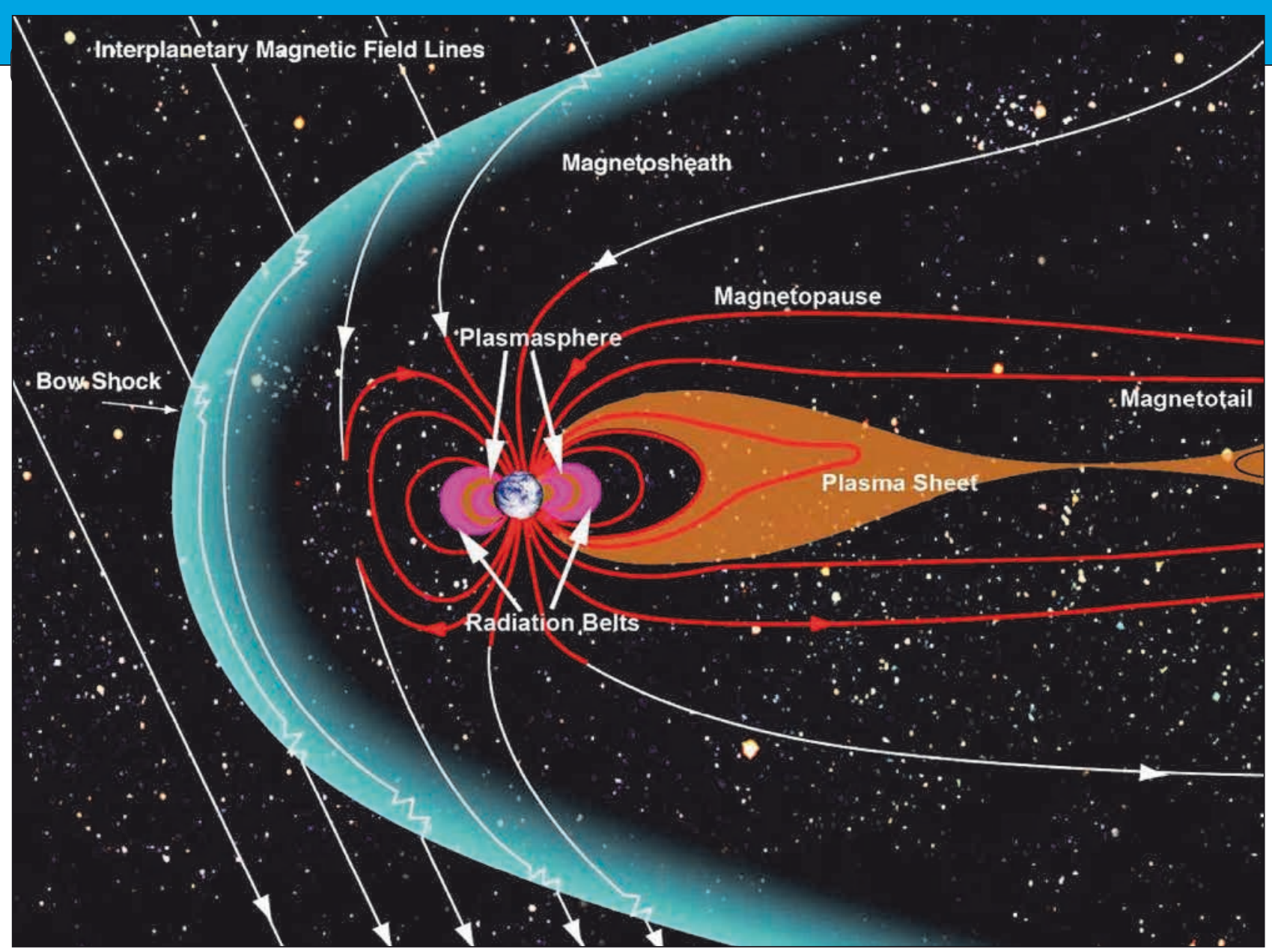

1. ábra. A magnetoszféra szerkezete (Fotó: NASA)

zódik a felső tartományokra, hatása leér egészen a bolygó felszínéig.

Az egyik legmeghatározóbb űridőjárási hatás, ami a Föld felső légkörét éri, a Napból felénk áramló energia- és részecskesugárzás (napszél), ami, ha akadály nélkül elérné bolygónk felszínét, nemcsak a szénlánc alapú élet minden formáját semmisítené meg, de gyakorlatilag szinte „elfújná" teljes atmoszféránkat.

A Föld azonban - a (méretéhez képest is jelentős) mágneses terének és az ebből adódóan kialakult buroknak, a magnetoszférának köszönhetően - több mint 3,5 milliárd éve hordoz életet, a bioszférát. Az emberiség ehhez a bioszférához tette és teszi hozzá az utóbbi néhány évszázadban mindazt a technikai vívmányt, eszközrendszert és szolgáltatást, amivel életét és vele az egész bolygót alapvetően megváltoztatta. Ezt nevezzük technoszférának (2. ábra). Mind a bioszférára, mind a technoszférára nagyon komoly hatással van az üridőjárás (space weather).

\section{Az ÜRIDŐJÁRÁs}

Az űrkutatás és gyakorlati alkalmazási területei folyamatosan és dinamikusan fejlődő és bővülő szektorában az űridőjárás vizsgálata kiemelten fontos.

A Napból és a galaktikus háttérsugárzásból Földünket rendszeresen, változó mértékben éri nagyenergiájú röntgen- és gammasugárzás, valamint részecskezápor, ami a földi mágneses térrel kölcsönhatásban hozza létre a sugárzási öveket, és mágneses viharokat idéz elő a magnetoszférában. Ma már tudjuk, hogy ezek a hatások a teljes bioszféra működésén túl az ürtevékenységen alapuló technikai eszközeinket is befolyásolják, sőt egyes vizsgálatok még az emberi társadalmi-gazdasági folyamatokban is kimutattak naptevékenységgel korrelációban lévő változásokat.

A mai emberiség életét alapvetően meghatározó számos szolgáltatás, mint a meteorológia, a hírközlés, a távközlés, a navigáció, a távérzékelés, a katonai hírszerzés és egyéb katonai tevékenység, műholdak egész rendszerén alapul. Jelenleg közel 8000 üreszköz kering a Föld körül (és még ennél is nagyobb számú ún. űrszemét, ami szintén veszélyforrásként jelentkezik). Nyilvánvaló tehát, hogy minden ma élő ember életét alapvetően érinti, ha ezek az üreszközök rövidebb-hosszabb időre, vagy akár véglegesen használhatatlanná válnának egy üridőjárási esemény bekövetkezésekor. Előfordulhat az is, hogy hirtelen megváltozhat a keringő objektum pályája, ami akár az űreszköz elvesztéséhez is vezethet, ahogy az 2012-ben történt az akkor már 10 éve működő, nagyméretű, 8 tonnás távérzékelő műhold, az Envisat esetében.

Több nagy napkitörést is feljegyeztek az ipari forradalom kezdete óta. A napkitörés erősségére jellemző öt fokozatú $(A, B, C, M, X)$ logaritmikus skálán igazán jelentős eseményről az X fokozat esetén beszélünk. 1989-ben Kanadában okozott nagyon jelentős gazdasági károkat egy X19es, azaz az X1-nél 19-szer erősebb napkitörés, sokmillió háztartásban áramkimaradást idézve elő. Azonban 1859ben az ún. Carrington-esemény egy X190-es, azaz az X1nél 190-szer, az 1989-es eseménynél tízszer erősebb napkitörés következett be.

Valamennyien el tudjuk képzelni, mit okozhat egy, az 1859-es kategóriához hasonló méretű esemény a mai civilizáció életében. Az űreszközöket nemcsak a nagyenergiájú sugárzás, de a sugárzási övekből kicsapódó nagyenergiájú, sokszor relativisztikus részecskék is teljesen tönkretehetik, gyakorlatilag „elsöpörve” a technoszféránkat üzemeltető eszközöket. Ezáltal akár teljesen össze is omolhat 


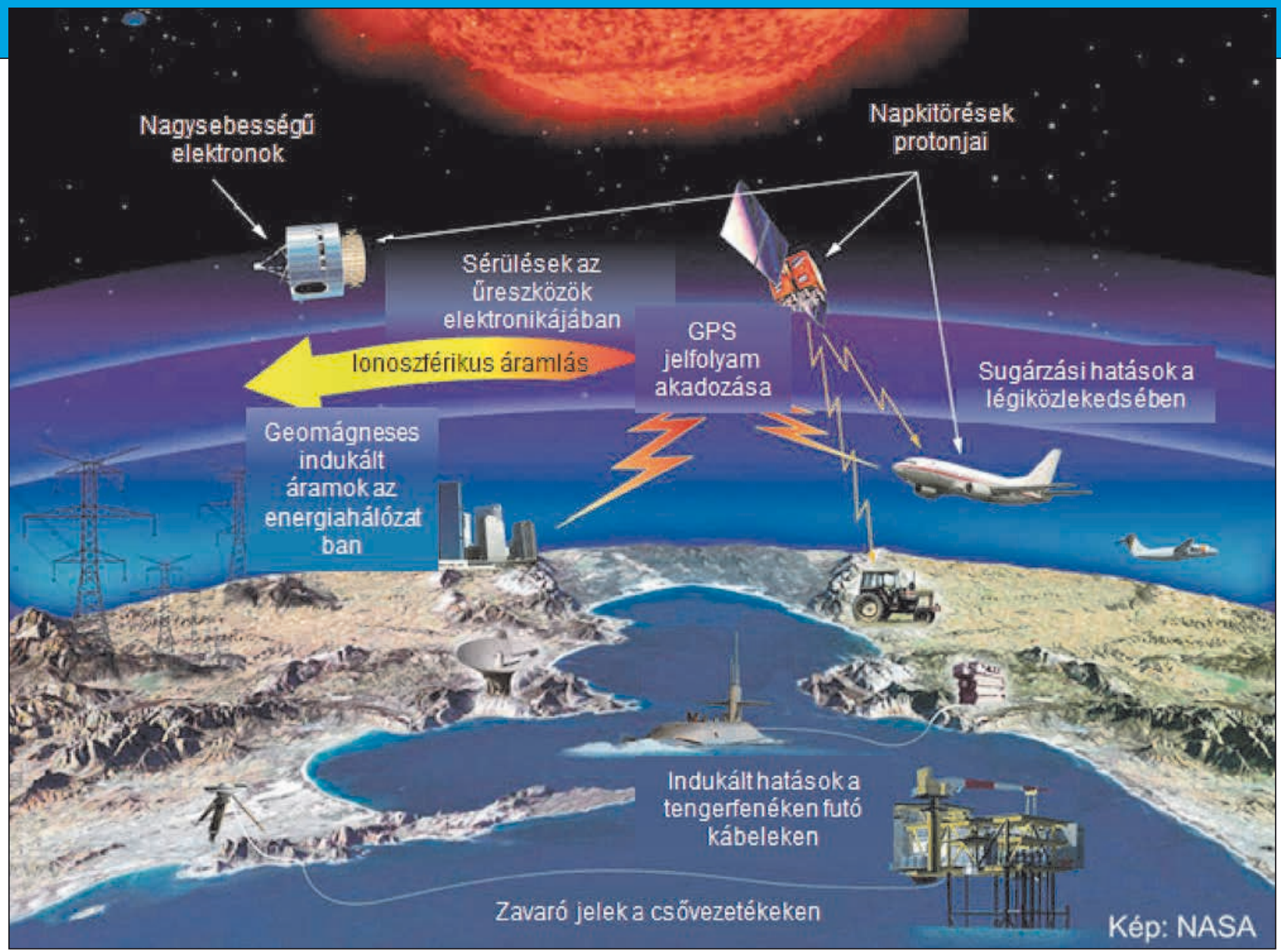

2. ábra. A technoszféra (Grafika: NASA, a magyar felirat a szerzők munkája)

a földi hír- és távközlés, légiforgalmi irányítás, navigáció stb. További károkat okoz egy ilyen esemény a villamosenergia-átviteli földfelszíni rendszereinkben áramokat indukálva, sőt egyéb csővezetékeket is tönkretehet az elektrokémiai korrózió jelensége is. Mivel a ma élő ember teljes mértékben a mai technológiákra alapozza mindennapjait, egy ilyen esemény nem 200 évvel röpítene minket vissza az időben, hanem (túlzás nélkül) a kőkorszakban találnánk magunkat. Az űridőjárás vizsgálata tehát nem a kutatók hóbortja, hanem alapvető nemzetgazdasági és nemzetbiztonsági kérdés.

\section{A MAGNETOSZFÉRA ALAPVETŐ FOLYAMATAI}

A magnetoszféra a mágneses tér és elektromosan töltött részecskék elegyének (plazma) összessége, amelyen áthaladnak a világürből, illetve a Föld felszínéről származó elektromágneses hullámok. Így az itt előforduló jelenségek, amelyek vizsgálata döntő fontosságú az űridőjárásban, e három „szereplő” kölcsönhatásából születnek meg.

Az egyik legfontosabb ilyen kölcsönhatás a plazmaszférában zajlik. Ez a magnetoszféra belső, hideg, kis energiájú (1 eV), nagy sűrűségú $\left(100-10000 / \mathrm{cm}^{3}\right)$, egyszeresen ionizált gázokat $(\mathrm{H}, \mathrm{He}, \mathrm{N}, \mathrm{O})$ és elektronokat tartalmazó, a földfelszín felett $1000 \mathrm{~km}$ távolságban kezdődő és kb. 4-5 földsugár távolságig tartó része. A földfelszíni elektromágneses aktivitásból (villámtevékenység, vulkanikus aktivitás, nukleáris vagy tektonikus jelenségek) származó rádióimpulzusok az erővonalak mentén terjedve kijutnak a Földdel együtt forgó, ám helyét és alakját dinamikusan változtató plazmaszférába, kölcsönhatásba kerülnek a részecskékkel, és jelentős távolságot bejárva jutnak vissza a felszínre, sokszor az ellentétes féltekén. Mivel átjárják a teljes plaz- maszférát, terjedési körülményeikre jól jellemző adatokat kaphatunk megfigyelésükből (3. ábra). Ezek a jelek jellemzően az ULF-ELF-VLF tartományba (1-20 kHz) tartoznak, így átalakítva hallhatóvá tehetők, mélyülő füttyre emlékeztető hangjuk alapján a whistler [magyarul: füttyös, fütyülő] elnevezést kapták, és tekinthetjük őket akár a szférák zenéjének is (Storey 1953, Carpenter 1963). Vizsgálatukkal egy nagyon hatékony plazmadiagnosztikai eszközhöz jutunk, mivel a Föld egyes helyein évente több tíz- vagy százezer, de az Antarktiszon akár évi több millió whistler is detektálható (Helliwell, 1965, Lichtenberger et al. 2008, Collier et al. 2011).

Egy másik, hasonlóan fontos kölcsönhatás a sugárzási (vagy Van Allen-) övekben a mágneses erővonalak által csapdába ejtett nagyenergiájú részecskék és elektromágneses hullámok között lép fel. A belső öv nagyjából 1,2-3 földsugár távolságban található és $100 \mathrm{keV}$ energiájú elektronok, valamint $100 \mathrm{MeV}$ energiájú protonok alkotják, míg a külső öv, amelyik 3-10 földsugár távolságban helyezkedik el, és legnagyobb sűrüségű része kb. 4-5 földsugárnál van (azaz a plazmaszféra határával, a plazmapauzával egybeesve), ahol akár relativisztikus (1-10 MeV) is lehet az elektronok energiája. E részecskék forrása a napszél, amelyből a belső magnetoszférába jutva mozgási energiájuk megnövekszik. A külső sugárzási övben elektromágneses hullámokkal „találkoznak” és kölcsönhatásba kerülnek, amelynek eredményeként energiájuk jelentősen megnő. Ez az energiatartomány már komoly károkat tud okozni a magasabb, akár geoszinkron pályán keringő műholdak, üreszközök elektronikájában is. Ma már ismert a tény, hogy e részecskék, bizonyos elektromágneses hullám-részecske kölcsönhatások során többletenergiához juthatnak és ilyenkor kicsapódva, az üreszközök számára veszélyes, relativisztikus részecskék már képesek arra, hogy lejussa- 
nak az alacsonyabb pályákon keringő eszközökig is (pl. Horne et al. 2005, Bortnik et al. 2008).

Végül fontos megemlítenünk egy harmadik kölcsönhatástípust is, ami a Napból a belső magnetoszférába jutó részecskéknek a Lorentz-erő által okozott, erővonal menti spirálmozgásán túl, az inhomogenitások és a gravitációs tér jelenléte miatti járulékos sodródásából („drift”) adódik, merőlegesen az inhomogenitás gradiensére és a gravitációs térre, valamint a részecskék pozitív / negatív töltésének függvényében ellentétes irányú. Ez a jelenség egy keletinyugati gyűrủáram, amelynek mágneses tere gyengíti a földi mágneses teret, részecskéi közepes energiájúak (10 keV-200 keV, 10-100/cm ${ }^{3}$ ).

$A z$ űridőjárási eseményeket tehát röviden úgy foglalhatjuk össze, hogy a Napból érkező nagyenergiájú részecskék egyrészt bejutnak a belső magnetoszférába, megerősítik a gyűrüáramokat és gyengítik a földi mágneses teret, valamint hatásukra áram keletkezhet az ionoszférában vagy akár a felszínen is. A nagyenergiájú részecskék továbbá egyrészt veszélyt jelenthetnek a magasabb pályákon keringő űreszközökre, másrészt a sugárzási övekben a részecske-hullám kölcsönhatások során extra energiához juthatnak és kicsapódva már alacsonyabb pályájú űreszközökre is veszélyessé válnak, megváltoztatva, vagy akár végzetesen lerombolva bennük a félvezető átmeneteket.

Ahhoz, hogy az üreszközeinket megóvjuk a károsodástól (pl. riasztás esetén stand-by üzemmódba kapcsolva őket), jó modellekkel kell dolgoznunk, és - a Nap viselkedésének egyre pontosabb tanulmányozásán túl - folyamatosan monitoroznunk kell a Föld elektromágneses környezetét. E modellek egyik legfontosabb paramétere a plazmasűrüség, mint a hullám-részecske kölcsönhatások egyik legfontosabb adata. A töltéssűrűség meghatározásában jut nagyon fontos szerep a whistlerek mérésének és modellezésének, amelyen keresztül nagyon pontos közegjellemző adatokat tudunk meghatározni (Ferencz et al., 2001).

Elmondható, hogy az egész világ űrtevékenységében meghatározó űridőjárási vizsgálatok a NASA, az Orosz Ürügynökség (Roszkoszmosz) és az Európai Ürügynökség (ESA) tevékenységében is nagy hangsúlyt kapnak. Az ESA űrkörnyezet- és Föld-figyelő programjainak célja (Space Situational Awareness, SSA és Earth Observation, EO) az űridőjárás, az ürszemét és a földközeli objektumok figyelése és a lehetséges riasztások, beavatkozások módszereinek kifejlesztése. Ezek olyan új szolgáltatások, amelyek hamarosan a már eddig felsorolt, űrszegmensre alapuló szolgáltatásokhoz hasonló tudományos és gazdasági jelentőséggel rendelkeznek majd.

$E$ projektek részben földi, részben müholdas megfigyeléseket és méréseket használnak. Ebben a cikkben csak a műholdas mérésekről ejtünk szót.

\section{MAGYAR HULLÁMMÉRÉSEK MÜHOLDAKON}

A műholdak segítségével közvetlenül tudjuk mérni azokat az adatokat és paramétereket, amelyekre modelljeinkben szükségünk van, azonban nyilván drágább és bonyolultabb mérésekkel, mint a földi megfigyelések esetén.

Magyarországon az ELTE Geofizikai és Ürtudományi Tanszék Ürkutató Csoport számos hullámmérési kísérlet-

ben vesz részt az Orosz Tudományos Akadémia Űrkutatási Intézetével (IKI) és a Roszkoszmosszal együttműködve, valamint számos más űridőjárási műholdas és földi kísérlet résztvevője az ESA, és más nemzetközi szereplők partnereként.

A Föld körüli műholdas, elektromágneses, elsősorban VLF-tartományba eső hullámmérések alapját a SAS (Signal Analyzer and Sampler) műszercsalád jelenti, amelynek első változata az Interkozmosz-24 műhold fedélzetén startolt még 1989-ben, és több évig sikeresen végezte a hullámméréseket.

A továbbfejlesztett SAS-2-K2-es 2006-ban a Kompasz-2 orosz-magyar-ukrán műhold fedélzetén repült, és a magyar mérésekkel sikerült először igazolni az ún. vezetett terjedést whistlerek esetében müholdas adatokból (Ferencz et al. 2009).

2012-ben sikerrel állt pályára a Csibisz-M orosz-magyar-ukrán műhold a Progressz teherürhajó segítségével, fedélzetén a SAS-3-Ch műszerrel. A küldetés célja a földi villámtevékenység és az ahhoz kapcsolódó röntgen-, gamma-, és VLF-hullámok vizsgálata volt (ahogy azt a műhold nevében található $M$, azaz „molnyija”, villám is jelzi). Ennek a kísérletnek a folytatása lesz a Csibisz-Al (,atmospheric and ionospheric"), amely kifejezetten a viharzónák optikai, röntgen felvillanásainak, elektromágneses aktivitásának tanulmányozását tűzte ki célul, részben a Vénusz, részben a földi klímaváltozás folyamatainak tanulmányozásához is segítséget nyújtva (Novikov et al., 2009).

2013-ban startolt az orosz-magyar együttműködésben készült Vernov/RELEK műhold, fedélzetén a SAS-3-R műszerrel, ennek a kísérletnek elsődleges célja a nagyenergiájú, relativisztikus elektronok vizsgálata volt.

Szintén 2013-ban, egy 5 órás űrséta keretében sikerrel szerelte fel két orosz kozmonauta a Nemzetközi Ürállomás (ISS) orosz szegmensének külső felületére az Obsztanovka kísérlet műszerét. Ez az orosz-magyar-ukrán-lengyelsvéd-angol együttműködésben készült, két egységből álló műszeregyüttes a nagy kiterjedésű fémtárgy, az űrállomás földi ionoszférában, plazmában történő mozgása során fellépő jelenségeket vizsgálta. Ennek a kísérletnek a második fázisa, az Obsztanovka-2 magyar ötlet alapján kiegészül három „űrbójával” és továbbfejlesztett hullámtani mérésekkel is, az ISS külső környezetének részletesebb tanulmányozása érdekében.

A Trabant („Darabont”, azaz „Kísérő”) orosz-magyar űrkísérlet pedig olyan egyedülálló, rendkívül komoly műszaki kihívásokat jelentő küldetés lesz, amely - reményeink szerint korábban soha nem tapasztalt részletességű űridőjárási vizsgálatokat tesz majd lehetővé. 


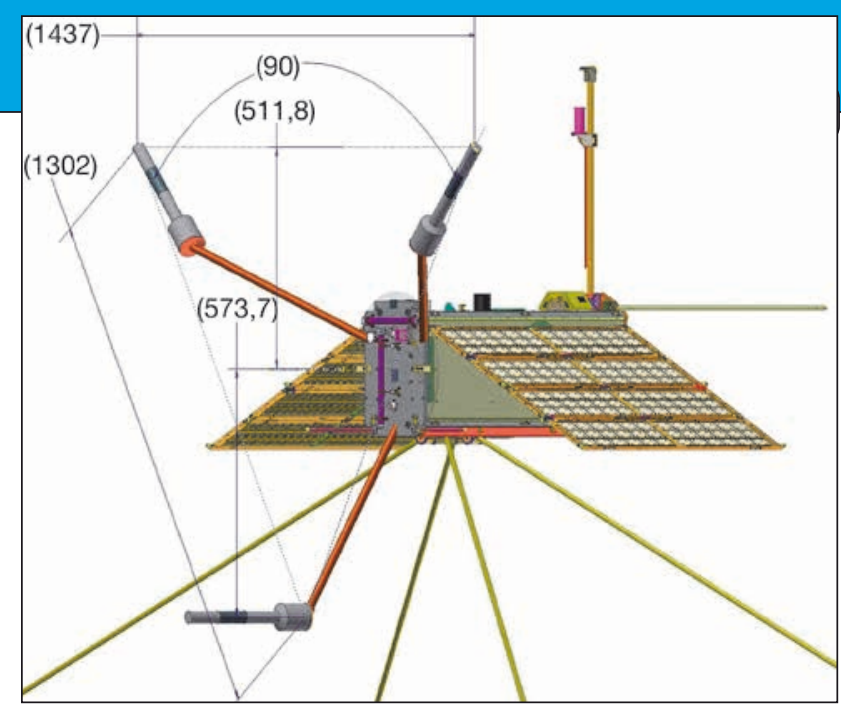

A műhold hullámméréseket végző legfontosabb műszere a SAS-3-T egység lesz, de magyar fejlesztésű lesz a fedélzeti számítógép, a digitális adatgyűjtő, a nagysebességű adatátvitelt megvalósító fedélzeti adó és telemetria rendszer is. Ez azt jelenti, hogy a teljes egység több mint 50\%-a magyar fejlesztés, azaz az eddigi legnagyobb arányú hozzájárulást fogja adni a magyar úripar egy kiemelkedő tudományos műhold megépítéséhez. Ezzel Magyarország nemcsak egy, a világ élvonalába tartozó tudományos-technológiai kísérlet részese lesz, de alanyi jogon az összes tudományos adat és eredmény elsők közötti felhasználására is jogosulttá válik, valamint komoly referenciát szerez hasonló missziókban való részvételhez is.

A mühold legnagyobb újdonsága - ami elvileg nemzetközi szinten is megkülönbözteti minden eddigi hasonló űrkísérlettől - az a célkitűzés, hogy a műhold minden, a pályája mentén mért adatot nagy felbontásban rögzít és továbbít a Földre. Ez a teljes múködési időt (kb. 5 év) alapul véve 250 TByte adattömeg, azaz napi közel 125 GByte adat begyűjtését és tárolását, valamint továbbítását jelenti a földi vevőállomások felé. Mivel a műhold keringési ideje kb. 90 perc, és 3 földi vételi pontnál többet jelenleg nem lehet feltételezni, ez napi két áthaladást, és körülbelül 10 perces átvonulási időt feltételezve egy földi vételi pont felett azt jelenti, hogy naponta csak átlagosan 60 perc idő áll rendelkezésre az adatok lesugárzására („down link”). Ez még egy több tonnás hírközlési műhold számára is komoly feladat, egy kisméretű, kis össztömegű mikroműhold esetén pedig óriási műszaki kihívás.

További nehézséget jelent, hogy a Trabant mikroműhold esetében kifejezett preferencia a tervezés során, hogy elektromágnesesen rendkívül kis zajú, azaz „csendes” műholdat kell megépíteni, lehetővé téve a zaj minimalizálást, és így tudományos szempontból a lehető legpontosabb elektromágneses méréseket végezve a Föld ionoszférájában.

A műhold saját működési, úgynevezett „housekeeping” adatait az S-sávban (2,2-2,4 GHz), míg a tudományos mérési adatok „down link” lesugárzását az X-sávban (8 GHz) végzi majd. Ez a földi vevőállomások számára is kihívást jelent, mert mindkét sávban nagy adatsebességű és kis zajú vétel feltételeinek kell megfelelni.

A SAS-3-T műszer a korábbi változatok továbbfejlesztésével képessé válik arra, hogy a $0,1 \mathrm{~Hz}-80 \mathrm{kHz}$ tartományban kis zajjal, folyamatosan mérje az elektromágneses sugárzás mind a hat komponensét. Ez a világon jelenleg egyedülálló hullámmérési követelményt jelent.

Egy nagyfrekvenciás (100-150 MHz tartományban müködő) plazmasűrűség-mérő egység fogja mérni a plazmasűrűség-fluktuációkat, ebben a mérésben szintén szerepet kapnak magyar mérnökök.

Összegezve elmondhatjuk, hogy a Trabant-küldetés forradalmian új méréseket eredményezhet az űridőjárási kutatásokban és az a tény, hogy ebben a kísérletben kiemelke-

4. ábra. A Trabant múhold szerkezeti rajza (Illusztráció: a szerzők tulajdona)

dő a magyar részvétel aránya, hatalmas elismerés a magyar űrkutatás és űripar szereplőinek.

\section{HIVATKOZÁSOK}

Bortnik J., Thorne R. M., Meredith N. P., 2008: The unexpected origon of plasmaspheric hiss from discrete chorus emissions. Nature 452, 62-66. DOI: 10.1038/ nature06741;

Carpenter D. L., 1963: Whistler evidence of a knee in the magnetospheric ionisation density profile. J. Geophys. Res. 98, 1676 DOI: 10.1029/jz068i006p01675;

Collier A. B., Lichtenberger J., Clilverd M. A., Steinbach P., Rodger C. J., 2011: Source region for whistlers detected at Rothera, Antarctica. J. Geophys. Res. 116, A03219, DOI: 10.1029/2010JA016197;

Ferencz Cs., Ferencz O. E., Hamar D. Lichtenberger J. 2001: Whistler Phenomena, Short Impulse Propagation. Astrophysics and Space Science Library Kluwer Academic Publisher, ISBN 0-7923-6995-5, Dordrecht, Netherlands DOI:10.1007/978-94-015-9642-8;

Ferencz O. E., Bodnár L., Ferencz Cs., Hamar D., Lichtenberger J., Steinbach P., Korepanov V., Mikhaylova G., Mikhaylov Yu., Kuznetsov V. 2009: Guided whistlers propagating in higher order guided mode and recorded on board of Compass- 2 satellite by the advanced Signal Analyzer and Sampler SAS2. J. Geophys. Res. 114., A03213, DOI: 10.1029/2008JA013542;

Helliwell R. A., 1965: Whistlers and related ionospheric phenomena. Stanford University Press, Stanford;

Horne R. B., Thorne R. M., Shprits Y. Y., Meredith N. P., Glauert S. A., Smith A. J., Kanekal Sh., G., Baker D. N., Engebretson M. J., Posch J. L., Spasojevic M., Inan U. S., Pickett J. S., Decreau P. M. E., 2005: Wave acceleration of electrons in the Van Allen radiation belts. Nature 437, 227-230. DOI: 10.1038/nature03939;

Lichtenberger J., Ferencz Cs., Bodnár L., Hamar D., Steinbach P., 2008: Automatic Whistler Detector and Analyzer (AWDA) system. Automatic Whistler Detector. J. Geophys. Res. 113, A12201, DOI:

10.1029/2008JA013467;

Novikov D. I., Klimov S. I., Korepanov V. E., Marusenkov A. A., Ferencz Cs., Lichtenberger J., Bodnár L., 2009: Magnitno-volnovoj kompleks mikrosputnika "Tsibis-M" dla izutsenia kozmitseskoj pogodi. In: Missia „Tsibis-M”, ed. by Hazirova R. R., IKI-RAN Moskva, pp. 78-89;

Storey L. R. O., 1953: An investigation of whistling atmospherics. Phil. Trans. R. Soc.,. Series A 246, 113-141 DOI: 10.1098/rsta.1953.0011. 